\title{
TELAAH KRITIS UPAYA PENEGAKAN HUKUM TERHADAP TINDAK PIDANA KEKERASAN DALAM RUMAH TANGGA
}

\author{
Fransiska Novita Eleanora \\ Fakultas Hukum Universitas Bhayangkara Jakarta Raya \\ Jl. Perjuangan No. 81, Bekasi-Jawa Barat 17143 \\ fransiska.novita@dsn.ubharajaya.ac.id \\ Elfirda Ade Putri \\ Fakultas Hukum Universitas Bhayangkara Jakarta Raya \\ Jl. Perjuangan No. 81, Bekasi-Jawa Barat 17143 \\ Elfirdade.putri@gmail.com
}

\begin{abstract}
ABSTRAK
Maraknya tingkat kekerasan dalam rumah tangga menyebabkan penderitaan bagi korban dan karena dapat menimbulkan taruma yang berkepanjangan dan untuk memulihkannya perlu adanya tindakan rehabilitasi dan untuk itu perlu diberikannya sanksi yang tegas bagi pelaku. Karena dengan pemberian hukuman memberikan perlindungan dan penegakan hukum terhadap hak perempuan, sesuai dengan ketentuan undang-undang Nomor 23 Tahun 2004 tentang penghapusan kekerasan dalam rumah yaitu melindungi akan hak asasi perempuan. Rumusan dari masalah ini bagaimana telaah kritis upaya dari penegakan hukum terhadap tindak pidana terhadap kekerasan dalam rumah tangga. Tujuannya adalah untuk mengetahui penegakan hukum terhadap tindak pidana kekerasan dalam rumah tangga, sedangkan metode yang digunakan adalah yuridis normatif dimana didasarkan pada konsep, asas, dan teori serta pertauran perundangan dan juga literatur yang berkaitan dengan telaah kritis terhadap upaya penegakan hukum dari tindak pidana terhadap kekerasan dalam lingkup rumah tangga, dan hasil dari pemelitian (temuan) bahwa penegakan hukum dapat dilaksanakan jika menerapkan sanksi yang berat seperti hukuman seumur hidup kepada pelaku jika akibat perbuatannya menimbulkan luka berat bagi korban, kesimpulannya bahwa efektivitas dari penegakan hukum itu sendiri dipenggruhi oleh beberapa faktor, yaitu dari hukum itu sendiri, penegak hukum, sarana dan juga fasilitas, masyarakat dan kebudayaan.
\end{abstract}

Kata Kunci : penegakan hukum, tindak pidana, rumah tangga

\begin{abstract}
The rampant level of domestic violence causes suffering for victims because it can cause prolonged trauma and to restore it is done by rehabilitation measures for victims as well as providing strict sanctions for perpetrators. Because the provision of punishment provides protection and law enforcement for women's rights, in accordance with the provisions of law number 23 of 2004 concerning the elimination of violence in the home that is protecting the human rights of women. The formulation of this problem is a critical study of law enforcement efforts against domestic violence. The aim is to find out the law enforcement of domestic violence, while the method used is normative juridical which is based on concepts, principles, theories and regulations as well as literature relating to critical review of law enforcement efforts on violence in the home stairs, and get the results of research (findings) that law enforcement can be implemented if applying severe sanctions such as life imprisonment to the offender if the consequences of his actions cause serious injuries to the victim, the conclusion that the effectiveness of law enforcement itself is influenced by several
\end{abstract}


factors, namely from law itself, law enforcement, facilities and also facilities, society and culture.

Keywords: law enforcement, crime, household

\section{A. PENDAHULUAN}

Perlindungan akan hak hak asasi dari setiap manusia sudah menjadi tanggungjawab dari Negara, Pemerintah dan hukum untuk selalu melindugi warganya tanpa terkecuali, sehingga dapat dikatakan penegakan hukum berkaitan dengan rule of law yaitu, supremasi dari aturan hukum dimana seseorang boleh dihukum, jika memang dianggap melanggar aturan dalam hukum, adanya bukti bahwa seseorang sudah melakukan perbuatan yang dianggap melanggar hukum, sehingga harus diberikan sanksi yang sesuai dengan perbuatannya, dan yang ke dua adalah kedudukan yang sama dimata hukum, artinya tidak adan tebang pilih atau tindakan yang diskriminasi, jika salah tanpa memandang siapa orangnya diberikan hukuman, dan yang ketiga adalah terjaminnya akan hak asasi setiap manusia melalui undangundang yang ada dan berdasarkan putusan dari pengadilan ${ }^{1}$.

Hukum positif Indonesia juga mengatur tentang hukuman atau sanksi yang diberikan kepada pelaku yang dianggap melanggar aturan hukum, termasuk juga dalam tindak pidana kekerasan dalam rumah tangga, kekerasan yang dimaksud disini memnimbulkan rasa yang tidak mengenakkan kepada salah satu pihak yang menjadi korban, dan selalu kebanyakan dari korbannya adalah perempuan karena dianggap sangat rentan dengan kekerasan, tetapi tidak menutup kemungkinan juga bisa berdampak kepada anak dalam lingkup akan rumah tangganya ${ }^{2}$

Jika terbukti melakukan kekerasan tentunya selain diberikan sanksi berupa pidana pokok juga diberikan sanksi tambahan, diberikan ancaman hukuman yang seberat-beratnya apabila akibat perbuatannya menimbulkan apa yang disebut dalam ketentuan pasal 90 kitab undang-undang hukum pidana sebagai luka yang berat. Hukum ditegakkan agar hak-hak korban dari suatu tindak pidana dalam kekerasan dapat terpenuhi ${ }^{3}$ yaitu haknya untuk hidup dengan mengalami kekerasan maka ada hak dari korban yang dilanggar, pelanggaran dari hak korban tidak dibenarkan dan harus diberikan adalah hak untuk menuntut ganti rugi yang layak yang harus diberikan kepada korban.

Faktanya bahtera rumah tangga yang sudah dibangun sekian lama dapat hancur dengan sendirinya, dengan berbagai alasan, yaitu ketidakcocokkan dimana ujungujungnya terjadilah perceraian atau perpisahan ${ }^{4}$, atau karena adanya perselingkuhan dalam rumah tangga, atau pergi bertahun-bertahun dan meninggalkan rumahnya tanpa ada kabar atau informasi kepada keluarganya dan bukan hanya itu saja juga tidak memberikan nafkah kepada keluarganya, sehingga bisa diartikan itu juga

\footnotetext{
1 Rika Saraswati, (2006), Perempuan Dan Penyelesaian Kekerasan Dalam Rumah Tangga, Bandung : Citra Aditya Bakti, hlm. 34

${ }^{2}$ Ibid, hlm. 45

${ }^{3}$ Emilda Firdaus, (2015), Perlindungan Perempuan Korban KDRT Menurut HAM Di Indonesia, Yogyakarta : Genta Publishing, hlm. 32-33

${ }^{4}$ Ibid, hlm. 50
} 
sebagai penelantaran rumah tangga, dikarenakan tidak pernah memebrikan nafkah kepada istri dan juga kepada anak-anaknya.

Upaya penegakan hukum dalam mengurangi tindak pidana dalam kekerasan yang terjadi adalah dengan menerapkan selama ini dengan menerapkan hukuman pidana penjara dan denda, namun penerapan tersebut kurang dapat di anggap memuaskan perlu juga adanya rehabilitasi diberikan kepada pelaku, agar nantinya pada saat kembali kepada lingkungan atau keluarganya tidak mengulangi perbuatannya, dan dipastikan tidak ada gangguan kejiwaan dalam diri pelaku, selain itu diberikan juga pidana berupa tambahan yang dapat membattasi gerak gerik dari pelaku, jadi tidak hanya sebatas pidana penjara dan denda saja.

Berdasarkan pendahuluan diatas maka rumusan masalah yang akan dikaji adalah bagaimana telaah kritis upaya penegakan hukum terhadap tindak pidana kekerasan dalam rumah tangga

\section{B. METODE PENELITIAN}

Metode penelitian dalam bidang hukum adalah penelitian normatif dan empiris, dimana penelitian yang normatif disebut dengan penelitian kepustakaan karena ditujukan pada penelitian yang tertulis seperti perundang-undangan, literatur, konsep, teori, yang berhubungan dengan data sekunder. Sedangkan penelitian yang disebut empiris adalah suatu metode yang dapat bermanfaat untuk melihat hukum yang berfungsi dalam arti yang benar-benar nyata dan juga meneliti bagaimana hukum tersebut bekerja dalam masyarakat, sehingga dilakukan secara observasi untuk melihat langsung bagaimana hukum itu bekerja ${ }^{5}$.

\section{PEMBAHASAN DAN ANALISIS}

\section{Penegakan Hukum}

Penegakan hukum nenurut pendapat dari Satjipto Rahardjo diartikan sebagai suatu konsep yang normatif, di mana dapat melaksanakan dan atau menjalankan apa yang ada dalam ketentuan dalam suatu perundang-undangan atau peraturan yang ada, dan penegakan hukum yang dimaksud selalu melibatkan manusia dan tingkah laku dari manusia saja, dimana dalam mewujudkan penegakan hukum dalam pelayanan yang publik dimana aparatur pelayanan yang publik harus menghindari cara-cara yang dianggap sebagai konvensional tetapi selalu menghalalkan segala cara-cara yang luar biasa.

Sejalan itu dengan itu mengacu juga dengan pendapat dari Barda Nawawi Arief lewat bukunya Didik S bahwa disebut dengan penegakan hukum pada dasarnya atau pada hakekatnya adalah penegakan dari hak sasi manusia, serta harus tegaknya kebenaran dan juga keadilan dan juga tidak adanya penyalahgunaan dari kekuasaan dan juga praktek dari favoritisme, yang diwujudkan dalam seluruh dari norma atau tatanan kehidupan dalam masyarakat, dimana perwujudannya itu dilaksanakan dengan melindunginya jika terjadi pelanggaran terhadap dari hak asasi manusia dengan menjalankan peraturan

${ }^{5}$ Johnny Ibrahim, (2010), Teori dan Metodologi Penelitian Hukum Normatif, Malang : Bayumedia Publishing,, hlm. 24 
perundang-undangan yang ada, sedangkan pelaksananya adalah penegak hukum sendiri demi mewujudkan keadilan, dan kepastian hukum juga kemanfaatan hukum yang ada. ${ }^{6}$

Undang-Undang Nomor 23 Tahun 2004 Tentang Penghapusan Kekerasan Dalam Rumah Tangga dimana Undang-Undang ini mengisyaratkan tidak bolah adanya kekerasan dalam bentuk ataupun wujud apapun kepada perempuan, adanya keadilan gender antara laki-laki dan perempuan karena melindungi akan hak-hak perempuan, yaitu hak asasinya dan melindungi korban, kekerasan yang sering menjadi perhatian bahkan meninggalkan kesakitan atau bekas di tubuh adalah kekerasan fisik dibandingkan kekerasan lainnya, kekerasan yang fisik dan bisa dilakukan pembuktiannya dengan melakukan pemeriksaan kedokter dan meninta surat mengebai visum et repertum yang menyatakan korban sudah menderita luka-luka pada tubuhnya akibat tindakan penganiayaan dan dengan demikian dapat mempidana pelaku. Kekerasan fisik ini dapat menyebabkan korban menderita psikis yaitu penderitaan kejiwaan yang parah dan perlu dilakukan dengan tindakan rehabilitas yaitu tindakan yang medis

Sedangkan faktor-faktor yang disebut sangat mempengaruhi dari penegakan hukum, adalah :

a) Faktor dari hukum itu sendiri, hukum yang dimaksudkan disini adalah hukum yang bersifat tertulis dan dibuat oleh pemerintah dan harus ditaati oleh seluruh lapisan masyarakat karena haukum yang dibuat itu mengikat setiap orang.

b) Penegak Hukum, harus menjalankan tugasnya sesuai dengan fungsi dan perannya masing-masing seduai dengan peraturan yang ada, dalam menjalankan tugasnya harus ada sikap yang profesionalisme dan juga keadilan serta menjadi panutan dan juga dipercaya dalam setiap anggota dari masyarakat

c) Sarana atau fasilitas yang mendukung dari penegakan hukum, dimana sarana atau fasilitas tersebut mencakup tenaga dari manusia yang terdidik dan juga terampil, serta peralatan yang juga baik, dan adanya organisasi yang dianggap baik pula serta keuangan yang cukup, jika saraana dan juga fasilitas memadai adalah merupakan bentuk keberhasilan dari suatu penegakan hukum.

d) Masyarakat, dimana masyarakat itu berada dan dimana juga hukum itu diterapkan, sehingga tiap lapisan dari masyarakat yang ada memahami dan mengethui hukum yang berlaku dengan penuh kesadaran dan akan pentingnya hukum ditengah-tengah masyarakat yang ada7.

e) Kebudayaan, sebagai hasil karya, dan cipta juga rasa dalam setap kehidupan umat manusia, dimana kebudayaaan mencakup dan mendasari nilai-nilai

${ }^{6}$ H. Asep Suparman (2013), Penegakan Hukum Terhadap Penyelenggaran Pelayanan Publik, Jurnal Wawasan Hukum, Vol. 29 No. 2 September 2013, hlm. 849-850

${ }^{7}$ Soeryono Soekanto, (2002), Faktor-Faktor Yang Mempengaruhi Penegakan Hukum, Jakarta : Raja Grafindo Persada, hlm. 21 
hukum yang berlaku, nilai-nilai yang dianggap baik dijalankan dan yang buruk dibuang8

Sehingga dari faktor penegakan hukm diatas dapat diartikan bahwa dari hukum itu sendiri berjalan sesuai dengan fungsinya jika pelaku dalam kekerasan dalam rumah tangga sudah melakukan tindakan yang membahayakan maka pelaku dapat diberikan hukuman yang sesuai dengan perbuatannya agar dapat memberikan efek jera, termasuk juga dengan peraturan pelaksana lainnya. Penegak hukum sebagai pelaksana dilapangan setidaknya memahami keadilan gender walaupun masuk dalam ranah privat namun tidak semuanya harus diselesaikan dengan mediasi, ataupun pidana penjara dan denda, setidaknya harus memberatkan pelaku dengan pemberian pidana tambahan dan konseling sehingga pelaku menyadari kesalahannya dan merasa mejadi terpidana itu tidak enak dan memberikan penderitaan juga, selain itu korban berhak mendapatkan perlindungan dari keluarganya, kepolisian, kejaksaan, pengadilan, lembaga sosial atau lainnya yang terkait dan adanya keterlibatan dari Pusat Pemberdayaan Terpadu Pemberdayaan Perempuan dan Anak (P2TP2A) Sedangkan faktor penegakan hukum dari sarana dan fasilitas terkait dengan luka akibat kekerasan fisik yang diderita oleh korban, dimana dari P2TP2A merujuk ke e=rumah sakit atau layanan kesehatan yang sudah memadai akan sarana dan prasaraanya seperti ruangan yang cukup, rujuakan dari pelaporan dan pencatatan, tempat layanan hukum, kesehatan dan pemberian obat, rehabilitasi sosial dan juga reintegrasi sosial yang dibutuhkan korban. Masyarakat yaitu adanya anggapan perempuan dan anak sering dijadikan objek dalam kekerasan dalam lingkup rumah tangga, dan jika terjadi kasus tersebut masyarakat mengetahui dan melaporkan kepada aparat penegak hukum, sedangkan faktor budaya karena adanya budaya patriarkhi yang mendominasi pihak laki-laki lebih berkuasa dibanding wanita serta karena ketidakpahaman akan adanya hak dan kewajiban masing-masing diantara para pihak ${ }^{9}$

\section{Kekerasan Dalam Rumah Tangga}

Merupakan suatu tindakan yang dilakukan di dalam rumah tangga baik itu oleh suami juga istri dan juga dilakukan anak dalam lingkup tangga serta berdampak buruk terhadap keutuhan secara fisik, juga psikis dan keharmonisan dalam hubungan sesuai dengan yang termaktub dalam ketentuan pasal yang ke-1 Undang-Undang Nomor 23 Tahun 2004 tentang penghapusan kekerasan dalam rumah tangga. Beberapa penyebabnya dikarenakan beberapa hal, yaitu :

a) Budaya patriarkhi, menempatkan pihak yang lebih berkuasa dan kuat diatas segalagalanya, sedangkan pihak yang lemah berada di posisi yang bawah, dalam

8 Sanyoto, (2008), Penegakah Hukum Di Indonesia, Jurnal Dinamika Hukum, Vol. 8 No. 3 September, hlm. 200

9 Sembiring, Helfrida, dan Muhammad Saleh, (2019), Efektivitas Penegakan Hukum Terhadap Kekerasan Dalam Rumah Tangga (Suatu Penelitian di Kota Banda Aceh), Jurnal Ilmiah Mahasiswa Bidang Hukum Kenegaraan, 3 (1), hlm. 54-56 
hal ini dapat dilihat bahwa pihak wanita berada dalam posisi yang sangat rentan dengan kekerasan.

b) Pandangan serta negatifnya pelabelan yang memang dianggap sangat merugikan, yaitu pihak laki lebih berani dan perkasa, juga macho serta kuat, sedangkan pihak dari perempuan lemah, mudah menangis, pandangan ini mengakibatkan wanita sering menjadi korban Kekerasan Dalam Rumah Tangga ${ }^{10}$.

c) Antara suami, dan istri tidak saling memahami dan juga mengerti sehingga jika terjadi permasalahan dalam keluarga, komunikasi tidak berjalan sebagaimana yang diharapkan

d) Kekerasan Dalam Rumah Tangga yang terjadi sering mendapat legitimasi dari masyarakat, seakan-akan muncul pandangan bahwa nantinya dapat dselesaiakan secara musyawarah atau kekeluargaan, dan bumbu dalam rumah tangga biasa jika terjadi percekcokan dapat diselesaikan secara baik-baik ${ }^{11}$.

e) Perselingkuhan atau hadirnya pihak ketiga dalam lingkup suatu rumah tangga juga bisa jadi faktor kekerasan, karena perhatian dan fokusnya hanya kepada pihak ketiga dan tidak lagi mempunyai perhatian untuk keluarganya, seakanakan keluarga diterlentarkan karena hadirnya orang ketiga.

Selain penyebab terjadinya diatas, perlu juga dilihat apa yang menjadi bentukbentuk terjadinya kekerasan tersebut, yakni ;

(i) Kekerasan secara fisik, menimbulkan sesuatu yang tidak enak pada tubuh, luka memar, cacat, dan jatuh sakit sehingga perlu mendapatkan perawatan atau pengobatan dari dokter, kekerasan ini juga dapat mengakibatkan penaniayaan baik secara ringan ataupun juga berat, dan biasanya untuk pembuktiannya bisa dimintakan visum et repertum kepada dokter, yang menyatakan bahwa telah terjadi kekerasan fisik yang menimpa pada wanita sebagai korban, dan dapat diserahkan kepada penyidik.

(ii) Kekerasan secara psikis, perbuatan yang mengakibatkan atau memunculkan rasa ketakutan dalam diri, dan hilangnya rasa percaya dalam diri, ketakutan yang bisa berlebihan, tidak terlihat oleh kasat mata, dan biasanya menimbulkan trauma atau terganggunya kejiwaan dan psikologi kepada seseorang, sehinga dapat berdampak yang lama bagi korban ${ }^{12}$.

(iii) Kekerasan secara seksual dimana kekerasan yang mengarah pada seksual, seperti dalam ucapan, simbol, atau perbuatan yang dianggap cabul, dan sejenisnya. Pemaksaan hubungan yang seksual terhadap seseorang yang dalam lingkup rumah tangganya untuk kepentingan dan tujuan tertentu.

(iv) Kekerasan secara ekonomi atau biasa disebut rumah tangga tang diterlantarkan, pada umumnya karena tidak memberikan nafkah kepada istri

10 Jamaa, La, (2014), Perlindungan Korban Kekerasan Dalam Rumah Tangga Dalam Hukum Pidana Indonesia, Jurnal Cita Hukum, 1 (2), hlm. 270

11 Yuliati Hotifah, (2011), Dinamika Psikologis Perempuan Korban Kekerasan Dalam Rumah Tangga, Jurnal Ilmu Psikologi Personifikasi, Vo. 2 (1), hlm. 70

12 Dewi Lestari, (2005), Kekerasan Dalam Rumah Tangga Terhadap Perempuan, Jurnal Hukum dan Pembangunan, Vol. 35 No. 3, Juli - September, hlm. 368 
dan juga anak-anaknya, dalam lingkup rumah tangganya, atau misalnya pergi berbulan-bulan tanpa adanya kabar berita dimana suami stidak pernah memberikan nafkah kepada keluarganya, padahal menurut hukum yang berlaku setiap orang karena persetujuan atau perjanjiannya berhak memberikan kehidupan, dan perawatan juga pemeliharaan kepada orang tersebut.

\section{Sanksi Terhadap Tindak Pidana Kekerasan Dalam Rumah Tangga}

Sanksi atau hukuman merupakan alat pemaksa guna ditaatinya suatu aturan atau kaidah yang sudah ditetapkan dalam masyarakat, termasuk disini adanya pemberian sanksi terhadap pelaku yang melakukan kekerasan dalam lingkup rumah tanga, sanksi dalam arti yang memberikan efek yang jera. Banyaknya kasus-kasus kekerasan dalam rumah tangga yang diselesaikan secara mediasi atau musyawarah dengan tujuan agar aib dari keluarganya tidak diketahui oleh banyak orang, dan dengan mediasi yang berakhir dengan perdamaian seringkali tidak menyebabkan pelaku menjadi sadar akan kesalahannya tetapi bisa melakukannya lagi dan berulang-ulang, dan jika dalam mediasi tidak ditemukan jalan keluar, barulah dilakukan penyelesaian melalui jalan atau jalur dari pengadilan.

Sehingga dengan sanksi penjara dan juga denda yang diberikan kepada pelaku masih dianggap sangat ringan dengan tercatat terhadap beberapa atau sejumlah dari sanksi berupa pidana dan penjara yang diterapkan antara 6 bulan juga atau berkisar antara 2 tahun 6 bulan dan yang telah diputuskan oleh dari Pengadilan Negeri yang juga dengan menggunakan beberapa pasal-pasal dalam Undang-Undang dengan Nomor 23 dan Tahun 2004 diantaranya adalah ketentuan dalam pasal 49 jo pasal 9 dan juga pasal 279 dari Kitab Undang-Undang Hukum Pidana untuk tindakan yang disebut penelantaran dan juga suami yang menikah tanpa adanya ijin dari istri. ${ }^{13}$

Sedangkan dari putusan oleh Pengadilan yang berupa adanya sanksi berupa pidana dan penjara yang dinggap lebih tinggi dan hingga sampai 6 tahun diputuskan karena adanya sejumlah berbagai kasus, yang memang didakwa dan juga dituntut karena atau dengan menggunakan beberapa pasal-pasal dalam Kitab Undang-Undang Hukum Pidana (yaitu dengan pasal 351, 352, 285, 286 jo 287, 289 dan 335 dan untuk kasus berupa penganiayaan terhadap anak dan juga perkosaan terhadap anak) sesuai ketentuan dalam pasal 81 dan 82 Undang-Undang dalam Nomor 35 Tahun 2014 tentang perubahan atas undang-undang dengan Nomor 23 Tahun 2002 dan ketentuan dengan pasal 287 dan juga dalam pasal 288 Kitab Undang-undang Hukum Pidana untuk kasus terhadap perkosaan yang dilakukan pada anak.

Sampai saat ini belum juga ditemukan adanya tuntutan dimana yang menggunakan adanya ancaman terhadap pidana serta penjara atau juga denda maksimal selain pidana pokok dan denda yang akan diberikan kepada pelaku, juga

13 Wantu, Fence M, "Mewujukan Kepastian Hukum, Keadilan dan Kemanfaatan DalamPutusan Hakim di Peradilan Perdata, Jurnal Dinamika Hukum, (Gorontalo) 12 (3), hlm. 480 
perlu diberikan pidana tambahan, dan sampai saat belum ada putusan dari pengadilan yang mengatur mengenai pidana tambahan terhadap pelaku Kekerasan Dalam Rumah Tangga ${ }^{14}$.

Ketentuan pasal dari 50 dari ketentuan dalam Undang-Undang dengan Nomor 23 dan Tahun 2004 adalah hakim dapat juga menjatuhkan pidana berupa tambahan, berupa:

a) Pembatasan dari gerak si pelaku baik yang memang menjauhkan sipelaku dengan korban dalam jarak atau jangka waktu tertentu, dan pelaku tidak mempunyai kebebasan bergerak, seperti biasanya, dimana kebebasannya dibatasi agar tidak melukai si korban, dan diberikan jangka waktu untuk tidak bertemu dengan korban, sehingga korban yang terluka bisa pulih dan tidak ketakutan satu bisa melupakan peristiwa yang dialaminya, dengan demikian secara perlahan-lahan korban dapat sembuh dari luka-lukanya dan dapat dipilihkan akan kesehatannya.

b) Penetapan dari pelaku mengikuti program dengan konseling dan dibawah pengawasan dari lembaga tertentu, dimana ${ }^{15}$ pelaku harus diberikan konseling akan tindakan yang dilakukannya sudah mengakibatkan kesalahan dan penderitaan bagi orang lain, sehingga perlu dilakukan semacam konseling bagi pelaku, dimana petugas Balai Pemasyarakatan atau disebut Balai Pemasyarakatan dapat menyiapkan modul untuk mendapatkan layanan konseling yang dibutuhkan.

Tujuan dari konseling ini adalah membangun adanya kepercayaan dari laki-laki atau suami dan biasanya dipisahkan, karena tidak semuanya mau menerima yang namanya konseling, dimana ada 4 tahapan yang biasanya dijalankan yaitu penyangkalan, juga prekontemplasi, dan kontempasi hingga pelibatan. Dan konseling yang diberikan adalah sebelum adanya putusan dari pengadilan, dan dimana pada saat sang istri mencabut laporannya dan dapat rujuk kembali serta konseling adalah merupakan sanksi berupa pidana tambahan, dan tidak menghapuskan kesalahan dari pelaku, tetapi proses pidana tetap berjalan sesuai aturan yang berlaku. ${ }^{16}$

Keadilan terhadap korban kekerasan dalam rumah tangga selain mendapatkan pemulihan terhadap kekearsan yang dialaminya, dengan adanya pidana tambahan ini bisa mengakibatkan atau berkurangnya penderitaan bagi korban, karena tidak semua korban KDRT akan mengakhiri bahtera rumah tangganya dengan perpisahan, tetapi setidaknya dapat merubah kondisi jiwa, dan psikologi dari suaminya, karena dengan menjatuhkan pidana belum tentu memberikan perubahan sikap kepada pelaku, tetapi dengan sanksi berupa

${ }^{14}$ Emei Dwinanaharti Setiamandani dan Agung Suprojo, (2018), Tinjauan Yuridis Terhadap Undang-Undang Nomor 23 Tahun 2004 Tentang Penghapusan Kekerasan Dalam Rumah Tangga, Reformasi, Vol. 8 No. 1, hlm. 40-41

15 http://ditjenpp.kemenkumham.go.id/hukum-pidana/677-penegakan-hukum-kejahatankekerasan-dalam-rumah-tangga.html, diakes, 18 Januari 2020

16 https://nasional.tempo.co/read/1149097/cerita-konseling-untuk-para-pelaku-kdrt, diakses, 21 Januari 2020 
pidana tambahan secara perlahan pelaku dapat mengontrol emosinya, dan dapat memulihkan kondisi rumah tangganya. ${ }^{17}$ Karena nilai yang disebut keadilan adalah bersifat relatif, dimana adil adalah memberikan haknya sesuai dengan porsinya, namun keadilan yang dimaksud dalam penegakan dari hukum adalah memberikan keadilan sesuai dengan hak dari korban, dengan membayar gani rugi yang sesuai, dan juga membayar biaya pengobatan, memberikan dalam bentuk sanksi serta menjauhkan korban dari pelaku dalam waktu yang lama, karena korban pasti akan takut dan trauma atau cemas bahkan kuatir jika bertemu dengan pelaku, dan dapat memberikan rasa keadilan kepada korban

\section{KESIMPULAN}

1. Penegakan hukum dalam tindak pidana kekerasan dalam rumah tangga dipengaruhi oleh faktor dari hukum itu sendiri, aparat penegak hukum, sarana dan fasilitas, serta masyarakat dan juga budaya

2. Pemidanaan terhadap pelaku tindak pidana kekerasan dalam lingkup rumah tangga tidak hanya diberikan sanksi pidana penjara dan denda saja tetapi juga pidana tambahan berupa pembatasan gerak pelaku dan juga konseling.

\section{DAFTAR PUSTAKA}

\section{Buku}

Saraswati, Rika, (2006), Perempuan Dan Penyelesaian Kekerasan Dalam Rumah Tangga, Bandung : Citra Aditya Bakti

Firdaus, Emilda, (2015), Perlindungan Perempuan Korban KDRT Menurut HAM Di Indonesia, Yogyakarta : Genta Publishing

Ibrahim, Johnny, (2010), Teori dan Metodologi Penelitian Hukum Normatif, Malang : Bayumedia Publishing

Soekanto, Soeryono, (2002), Faktor-Faktor Yang Mempengaruhi Penegakan Hukum, Jakarta : Raja Grafindo Persada

\section{Peraturan Perundangan}

Kitab Undang-Undang Hukum Pidana (KUHP)

Undang-Undang Nomor 23 Tahun 2004 Tentang Penghapusan Kekerasan Dalam Rumah Tangga

17 Iskandar, Dadang, (2016), Upaya Penanggulangan Terjadinya Kekerasan Dalam Rumah Tangga, Yustisi, 3 (2), hlm. 19 


\section{Jurnal}

Hotifah, Yuliati, (2011), Dinamika Psikologis Perempuan Korban Kekerasan Dalam Rumah Tangga, Jurnal Ilmu Psikologi Personifikasi, 2 (1), 62-75. DOI: https://doi.org/10.21107/personifikasi.v2i1

Lestari, Dewi, (2005), Kekerasan Dalam Rumah Tangga Terhadap Perempuan, Jurnal Hukum dan Pembangunan, 35 (3), 367-385. DOI: http://dx.doi.org/10.21143/ihp.vol35.no3.1516

Suparman, Asep, H, (2013), Penegakan Hukum Terhadap Penyelenggaran Pelayanan Publik, Jurnal Wawasan Hukum, 29 (2), 849-853

Sanyoto, (2008), Penegakah Hukum Di Indonesia, Jurnal Dinamika Hukum, 8 (3), 199204

Wantu, Fence M, (2012), "Mewujukan Kepastian Hukum, Keadilan dan Kemanfaatan DalamPutusan Hakim di Peradilan Perdata, Jurnal Dinamika Hukum, 12 (3), 479489

Jamaa, La, (2014), Perlindungan Korban Kekerasan Dalam Rumah Tangga Dalam Hukum Pidana Indonesia, Jurnal Cita Hukum, 1 (2), 249-272. DOI: $10.15408 /$ jch.v1i2.1467

Setiamandani Emei Dwinanaharti dan Agung Suprojo, (2018), Tinjauan Yuridis Terhadap Undang-Undang Nomor 23 Tahun 2004 Tentang Penghapusan Kekerasan Dalam Rumah Tangga, Reformasi, 8 (1) 37-46

Iskandar, Dadang, (2016), Upaya Penanggulangan Terjadinya Kekerasan Dalam Rumah Tangga, Yustisi, 3 (2), 13-22

Sembiring, Helfrida, dan Muhammad Saleh, (2019), Efektivitas Penegakan Hukum Terhadap Kekerasan Dalam Rumah Tangga (Suatu Penelitian di Kota Banda Aceh), Jurnal Ilmiah Mahasiswa Bidang Hukum Kenegaraan, 3 (1), 46-58

\section{Internet}

Penegakan Hukum Terhadap Kejahatan Kekerasan Dalam Rumah Tangga, http://ditjenpp.kemenkumham.go.id/hukum-pidana/677-penegakan-hukumkejahatan-kekerasan-dalam-rumah-tangga.html, (Aceessed, January 18, 2020)

Cerita Konseling Untuk Para Pelaku KDRT, https://nasional.tempo.co/read/1149097/cerita-konseling-untuk-para-pelakukdrt, (Aceessed, January 21, 2020) 